\title{
What motivates and inhibits Indian textile firms to embrace sustainability?
}

\author{
Anupriya Sharma and Sapna A. Narula ${ }^{*}$ (i)
}

\author{
* Correspondence: narulasapna@ \\ gmail.com \\ Department of Business \& \\ Sustainability, TERI School of \\ Advanced Studies, 10, Institutional \\ Area, Vasant Kunj, New Delhi \\ 110070, India
}

\begin{abstract}
Our study identifies the motivations and barriers to pursue sustainability for textile firms in India and the impact of these factors on firm's adoption of sustainable business practices. Our study is based on primary survey of 113 managers from textile firm who are responsible for taking decisions towards formulation of business policies, and drivers are the reasons why companies decide to pursue sustainable practices. Regression analysis shows that regulatory, market and economic factors are more significant in pushing firms to adopt sustainable practices, whereas initial cost of compliance is the biggest challenge in implementing these practices. The results of the study are extremely important in assisting firm managers in enhancing their understanding of factors for a successful environmental strategy and influencing them to embrace sustainability. The study also contributes to our understanding of environmental issues in textile supply chain and how it could be made environmentally more sustainable. Finally, implications to extend research on role of internal actors in the organisation in shaping and implementing environmental strategies are presented.
\end{abstract}

Keywords: Responsible business, Sustainability, Drivers, Barriers, Indian textile industry, Managerial perception

\section{Introduction}

Textiles and Apparel (T\&A) sector is one of the most significant industrial sectors and plays a major role towards contribution to national economy, employment generation and exports in developing countries (Karthik and Gopalakrishnan 2014). The worth of global textile industry is US\$ 2.5 trillion worldwide with $58 \%$ contribution from apparel sector and $42 \%$ share from textile sector. Amongst the major exporters of Textile \& Apparels (T\&A) globally, the top 10 exporting countries enjoy a share of $72 \%$ in global T\&A exports with China and Hong Kong maintaining the top position with 37\% share, followed by India with a share of $5 \%$ in 2017. It is then followed by Bangladesh, Germany, Italy, Vietnam and Turkey each having a share of 4\% (Ministry of Textile, Annual report 2017-2018).

Though, recognized as one of the most important industries from the economic point of view, at the same time this industry is subject to severe ecological and social problems throughout the supply chain (Shen et al. 2017; Allwood et al. 2015; Alkaya and Demirer 2014; Bonini et al. 2006; Defra (UK Department for Environment, Food and Rural Affairs) 2008). The main environmental problem associated with textile

(c) The Author(s). 2020 Open Access This article is distributed under the terms of the Creative Commons Attribution 4.0 International License (http://creativecommons.org/licenses/by/4.0/), which permits unrestricted use, distribution, and reproduction in any medium, provided you give appropriate credit to the original author(s) and the source, provide a link to the Creative Commons license, and indicate if changes were made. 
industry consists of water body pollution caused by discharge of untreated effluents. During production, the cloth passes through the various processes and chemical operations like sizing, desizing, bleaching, dyeing, printing and finishing and several dyes, chemicals are used in desired quality in fabrics and this causes environmental problems unless it is properly treated before disposal (Hasanbeigi and Price 2012; Dasgupta et al. 2015). The industry also generates air pollution prior to processing of fibres and during spinning and weaving it generates dust, cotton lint etc., which degrades working environment in the industry (Blackburn 2009; Allwood et al. 2008). Owing to these severe ecological impacts, the textile industry is counted amongst the heavily polluting industries. Earlier the concern for the environment was the most neglected area of the textile industry but with growing awareness on environmental protection due to the depletion of non-renewable resources, global warming and destruction to ecology (Kalliala and Talvenmaa 2000; Kane 2001; Da Silva and Teixeira 2008; Thiry 2011), this issue has gained acceptance worldwide that there is a need for more responsible approach to the environment.

The structural change within the industry is visible globally and the production of textile and clothing has increased significantly. India has second largest population in the world and hence, the demand for textile products in India is very large and is growing at an increasing rate (Assocham, 2010). As far as economy is concerned, over 45 million people in India are directly employed by the textile industry. Also, the business model for the textile industry is primarily export-oriented as India is the second-largest textile manufacturer and exporter in the world (Ministry of Textiles, 2017). India is also amongst the world's top producers of yarn and fabrics and second highest producer of cotton after China contributing about $21.5 \%$ of the world's total production (Ministry of Textiles, 2018). The presence of more than 3000 spinning and composite mills spread across the country makes India an outsourcing hub for the global textile and apparel supply chain (CITI 2018; Baskaran et al. 2012; Verma 2002). With huge economies of scale, low-cost labor force, sufficiency in raw materials and spinning capacities, India has emerged as one of the major players for various international brands and retailers as it's textile and clothing industry has shown steady growth in past few years (Gupta and Hodges 2012).

Being a diverse and heterogeneous sector by nature, the textile industry consists of traditional textiles and technical textiles. In general, the textile industry provides textile material for apparels. This segment is known as traditional textiles which consists of raw materials such as cotton, jute, silk wool etc., as it fulfils the basic needs of human beings. The textile industry can further be classified into two categories, the organized mill sector and the unorganized decentralized sector. The organized sector of textile industry represents the mills it could be a spinning mill ${ }^{1}$ or a composite mill ${ }^{2}$ (Simi 2012; Chugan 2011). Cotton is one of the most important cash crops and accounts for around $25 \%$ of the total global fibre production. The environmental issues associated with cotton production are humongous. More chemicals are used for cotton than for any other crop and its production requires immense quantities of water along with use

\footnotetext{
${ }^{1}$ Spinning Mill: Spinning is the process of converting cotton or man-made fibre into yarn to be used for weaving or knitting.

${ }^{2}$ Composite Mill: Composite mills are integrated large scale mills that integrate spinning, weaving and sometimes fabric finishing under one roof.
} 
of pesticides that contaminates the freshwater availability, thereby causing water pollution (Karthik and Gopalakrishnan 2014; G. Hansen and Schaltegger 2013). India is ranked first in the world in terms of cotton acreage with around 10.5 million hectares under cotton cultivation which is around 35\% of the world area. Emergence of environmental standards and labels along with the need for improvement on production and processing practices have further aggravated the prospects of the Indian cotton textile industry (Singh et al. 2013; Parvathi et al. 2009). Thus, addressing these sustainability issues and balancing the Triple bottom line (TBL) presents various opportunities and challenges for firms towards engaging in sustainability-oriented practices (Joyce and Paquin 2016; Akenji and Bengtsson 2014). Research in several industrial sectors (Dos Santos et al. 2007; Brunke et al. 2014; Beske et al. 2014; Sezen and Çankaya 2013; Tortella and Tirado 2011; Pullman et al. 2009; Chkanikova and Mont 2015) shows that firm managers' environmental attitude to be positively correlated to the adoption of sustainable business practices in the industry (DeSimone and Popoff, 1998 and Clemens 2001). Their perception towards sustainable business practices influences the formulation of business policies for a positive environmental impact (De Abreu 2015; Caniato et al. 2012; Arora et al. 2004; Rieple and Singh 2010). Towards taking this decision to improve their environmental performance, the managers are motivated by various factors such as preservation of resources (Theyel 2000; Goworek et al. 2012; Pedersen and Andersen 2014), legal regulations (Jeswani et al. 2008; Babiak and Trendafilov 2011), to enhancing its reputation and differentiating its product in the market (Chkanikova and Mont 2015; Jeswani et al. 2008; Søgaard Jørgensen et al. 2010; Wuet al. 2012). The road to sustainability, however, is not easy as firms encounter various internal and external constraints in form of cost (Schrettle, S. et al., 2014; Wu- et al. 2012), absence of mandatory regulations and policies towards implementation of environment friendly practices by government bodies and lack of requisite skills and capacities (Achabou and Dekhili 2015; Jeswani et al. 2008). These factors restrict firm mangers in adopting sustainable practices.

While examining the literature on textile industry (Shen et al. 2017; Achabou and Dekhili 2015; Allwood et al. 2015; Alkaya and Demirer 2014; Shen 2014; Abernathy et al. 2006; Herva et al. 2008; Gardetti and Torres 2017; G. Hansen and Schaltegger 2013; Goworek et al. 2012; Dasgupta et al. 2015; Diabat et al. 2014; Resta et al. 2013; Chico et al. 2013; Nieminen et al. 2007; Hong et al. 2010; Wenzel and Knudsen, 2005; Chiarini 2014), we came across two significant gaps on environmental management practices for textile industry: First, most of the primary surveys with the firm managers in context of textile industry are conducted in developed countries such as Europe, USA, Australia, UK and Denmark, whereas the research in the context of emerging economies like India remains highly unexplored (Gardetti and Torres 2017; Vajnhandl and Valh 2014; G. Hansen and Schaltegger 2013; Goworek et al. 2012; Joergens 2006). A lot of production centers are concentrated in developing countries like India, Bangladesh, Pakistan, and the research for these geographical regions is scanty. Secondly, previous studies reported in India focused largely upon technological as well as economic aspects of textile industry (Dasgupta et al. 2015; Diabat et al. 2014; Hiremath et al. 2012; Reddy and Ray 2011; Verma 2002; Shrivastava, 1995; Narayanaswamy and Scott 2001) whereas, we find hardly any study capturing the managerial perspective towards sustainability issues and practices from the textile sector in India. Thus, leaving a 
research gap to understand the organizational issues across the multiple states in the second largest cotton producer of the world i.e. India. Our study addresses these gaps by assessing the nature and extent to which adoption of sustainable business practices are affected by drivers and barriers for the textile industry. This study is significant keeping in view the momentum which is picking up with regards to the global markets and the standards they demand. Sometimes, firms in these countries are unable to lead up to these specifications. It is, hence, worthwhile to understand the motivations behind environmental adoption and barriers they encounter to pursue environmental practices. A lot of other South Asian countries are also engaged in similar exporting activities, the findings may not only be relevant for India but also for other textile producing countries including Bangladesh, Pakistan, etc. Previous research has also demanded that these issues to be examined in the context of developing countries (Lozano 2013; Wu- et al. 2012; Jeswani et al. 2008: Desore and Narula 2018). Thus, the primary aim of this research is to explore the motivations and barriers in adoption of environmentally sustainable strategies for the Indian textile industry.

Our paper is divided into six sections. In the first section, we briefly discuss the background in the context of the Indian textile sector. The second section presents a literature review on motivations and barriers for firms to embrace sustainability with special reference to the said sector. The detailed methodology for this study is discussed in section three. Results and analysis of our research are presented in section four and in the last section, we conclude by providing both managerial and research implications to advance future research in the area.

\section{Theoretical background}

\section{The concept of sustainable business practices}

Sustainability is taking from the earth only those resources that are easily renewable while doing no harm to the environment. This allows for the needs of the current generation to be met without affecting the potential needs of future generations (World Commission on Environment and Development, 1987 (WECD). Sustainable business revolves around the three Ps: People, Profit and Planet (Elkington 1998). Many authors have tried to define sustainable business from various dimensions like greening the production process, to working on supply chain and to adopting sustainability strategies. For instance, authors Eccles et al. (2012), defines sustainable business as a business that carries environment friendly business processes without leaving negative environmental impacts related to their activities, products and services thereby leading to cost savings, enhancement of firm's image and better risk management. Authors Azapagic and Perdan (2000); Welford (2005) defines "Sustainable business as a new, radical paradigm that considers the ecological, social and economic impacts in a way that will not compromise the needs of the future generations". The triple bottom line (TBL) perspective is relatively widely understood perspective for business models to support sustainable actions (Joyce and Paquin 2016). For any product to be sustainable, it needs not only to be profitable but also take into consideration environmental and social impact during its lifetime.

Some authors have also tried to define the sustainability in context of textile industry. For instance, as defined by Fletcher (2009), "A sustainable product is one that is manufactured in such a way that it has lowest possible adverse effect on the environment. e.g. by 
making the most efficient use of resources such as water and energy and which goes the extra mile to recover raw materials, e.g. by the recycling of as much water as possible or by recovering the heat from wastewater discharges". According to Hethorn and Ulasewicz (2008), sustainability within fashion means that "through the development and use of a thing or process, there is no harm done to the people or the planet and that thing or process, once put into action can enhance the well-being of the people who interact with it and the environment it is developed and used within." For our study, we have considered the definition given by authors Gardetti and Torres (2012), to define sustainability in context of textile industry. They define sustainability for the textile industry as a "means to reduce water use and wastage across the supply chain, reduction in chemical pollution and minimized the use of non- renewable sources". The textile industry is subject to severe ecological problems in most of the phases of supply chain. Sustainability issues concerning the textile supply chain are related to energy efficiency, water management, waste management, logistics from raw material procurement to textile production until fabric finishing. As per Chen and Burns (2006), full environmental impact of any textile product may be broken down into those associated with its production (renewability of raw materials and chemicals released during production and processing), maintainance (quality and nature of chemicals used for laundering and dry cleaning) and eventual disposal (products recyclability and biodegradability), this indicates that making production process sustainable can help to reduce resource consumption, waste generation and other associated costs for textile firms.

Literature presents various sustainability practices adopted by firms towards improving their environmental performance (Gardetti and Torres 2017; Resta et al. 2013; Fletcher 2008; Fletcher and Grose 2012; Zhu and Geng 2013). For instance, in a study on textile industry by authors Zabaniotou and Andreou (2010), firms reported use of waste generated during ginning of cotton to develop an alternative energy source for reduction of Greenhouse Gas (GHG) emissions. Chinese researchers (Hasanbeigi and Price 2012) reviewed and summarized various energy use and energy efficiency technologies and measures applicable to textile industry at each stage of spinning (high speed carding machines, use of light weight bobbins in ring frame), weaving (replacing the electrical heating system with steam heating systems for yarn polishing machines), wet processing (recover heat from hot rinse water, reuse of washing and rising water, discontinuous dyeing with airflow dyeing machine) and fibre production (use of light weight carbon reinforced spinning pot in place of steel reinforced pot, adoption of pressure control systems with variable frequency drive (VFD) in washing pumps in after treatment process etc.) which resulted in considerable reduction in total energy consumption and associated $\mathrm{Co}_{2}$ emissions of company within a time frame of less than 1 year. Towards water efficiency in textile production, authors Alkaya and Demirer (2014), proposed and implemented five sustainable production applications such as use of drop/fill washing method ${ }^{3}$ instead of overflow, reuse of stenter/ singeing cooling water, renovation of water softening system and various valves and fittings in water transmission system which further resulted in reduction of water consumption,

\footnotetext{
${ }^{3}$ Drop/fill washing versus overflow: In the drop/fill method of batch washing, spent wash water is drained and the machine is refilled with a fresh wash bath. The fabric or other substrate in the machine retains much of the previous bath, thereby reducing water use in textile processing by upto $53 \%$ in comparison to overflow.
} 
wastewater generation and energy consumption and helped manufacturing mill achieve various environmental and economic benefits. Product life cycles are shortening, and companies want to substitute their products at an increasing pace. Another study on sustainability transformation showed that by diversifying into new environmental markets (organic fibres) and redesigning products to be more environmentally sensitive (integrated production of natural fibres, replacement of natural fibres with artificial fibres etc) resulted in reduction of environmental impacts by using less pesticides and chemical fertilizers and also social benefits in form of eliminated health threats of pesticides and better working conditions (G. Hansen and Schaltegger 2013). Some empirical studies reported in literature have addressed sustainability issues based on application of green certifications by firms such as ISO 14000,Global organic textile standards (GOTS), ${ }^{4}$ implementation of principles given by Global reporting initiative (GRI), use of ecolabels, Oeko tex 100 (Almeida 2015; De Brito et al. 2008) and green product and process design considering the production technologies, the product characteristics and materials used (Niinimäki and Hassi 2011; Ozturk et al. 2015). The previous authors also proposed various strategies to make textile supply chains sustainable. For instance, for a study on Taiwan textile and apparel industry, factors such as green purchasing, cooperation with customers and eco-design were proposed as ways to implement Green Supply Chain Management (GSCM) practices (Wu- et al. 2012). In another study, authors investigated China's textile industry in addition to the automobile, power generating, chemical, and electric industry and suggested supplier collaboration, ecodesign and internal environmental management to implement GSCM practices (Zhu et al. 2005; Zhu and Sarkis 2006).

Researchers have also made efforts to study Indian textile industry from sustainability lens, for example, Baskaran et al. (2012), evaluated garment manufacturers and ancillary suppliers within Indian textile industry using the sustainability criteria for social factors (discrimination, abuse, human rights, pollution) in Tirupur city and made efforts to answer the questions related to challenges faced by the manufacturers to adopt sustainable practices towards exporting garments to foreign buyers. In another study, Rieple and Singh (2010), presented the value chain analysis for production of organic cotton tshirts thereby discussing the areas of inefficiency during each stage of production process for its UK and US retailers where they reported that use of organic cotton by firms resulted in lower cost of pest management, increased yield and reduced crop failure in the long run. A case study on city of Solapur in the state of Maharashtra was carried by Hiremath et al. (2012), to measure the impacts of textile industry on the environment, human health, biodiversity and the climate. The authors suggested a sustainable networking model with integration of information and communication technology (ICT) for mitigating the change and to achieve desired development goals. A study by authors Dasgupta et al. (2015), provided various technological insights towards effluent treatment for the textile industry consisting of membrane filtration, biological treatments, oxidation and crystallization etc. Thus, summarising the previous

\footnotetext{
${ }^{4}$ Global organic textile standards (GOTS): These standards define worldwide recognised requirements that ensure organic status of textiles including ecological and social criteria backed up by independent certification of the entire textile supply chain.

${ }^{5}$ Oeko-Tex 100: The standard Oeko-Tex 100 is a product label for textiles tested for harmful substances. If a product is labelled as Oeko-Tex certified, it is completely free from harmful chemicals and safe for human use.
} 
studies, we find limited research on analysing the intent for sustainability for Indian textile industry in comparison to the studies reported from other developed countries in this sector discussed above. Previous studies mainly examined the factors from developed country perspective and were mostly qualitative in nature. In light of absence of any comprehensive studies on the subject in developing countries, our paper addresses this gap and considers factors related to the product, process and supply chain by firms to implement sustainable practices.

\section{Drivers and barriers to sustainable business practices}

We define drivers as the reasons behind firm managers' decision to pursue sustainable practices and in the process, they face certain challenges or barriers to adopting these practices. These factors tend to shape the organizational strategy and have the power to influence the response of the firms (Babiak and Trendafilov 2011; Caniato et al. 2012; Elliot, 2013; Lozano 2013). Involvement and pressure from regulatory bodies towards environmental clearance have been reported by researchers as a significant driver towards motivating firm managers to adopt environment-friendly practices (Jeswani et al. 2008; Babiak and Trendafilov 2011; Lozano 2013; Ervin et al. 2013). Regulatory pressure has been a coercive power pushing firm managers to adhere to the environmental requirements (Delmas and Toffel 2004). Government support to textile companies towards their technological improvements, investment in R\&D and dyeing capabilities have led to various energy and carbon reductions in the industry (Wu- et al. 2012). Various environmental certification standards have also been proposed by environmental groups such as ISO 140001; Oeko tex 100, GOTS (Global organic textile standards), BCI (Better cotton initiative), etc., which restrict the use of hazardous materials and processes towards textile and clothing manufacturing thereby resulting in regulatory pressure. Various market related factors in form of competition and demand from buyers and manufacturers (Daub and Ergenzinger 2005), motive to gain a unique green position in the market and to improve company's reputation (Chkanikova and Mont 2015; Jeswani et al. 2008; Søgaard Jørgensen et al. 2010; Wu- et al. 2012) have also been reported to be of significant importance towards influencing the firm managers decision towards sustainable practices. Literature shows that (Christmann and Taylor 2001; O'Cass and Weerawardena 2010; G. Hansen and Schaltegger 2013) a higher level of competitive influences resulted in the development of competitive products (use of organic cotton waste to make bags, T-shirts), strengthened managers commitment towards environmental protection (Menguc et al. 2010). For some studies, competitive influences resulted in influencing firm managers to imitate and learn environmental management practices from its competitors and further resulted in the efficient utilization of firm's resources and improved performance. Various organizational factors in form of commitment from top management towards integrating sustainability into business practices, knowledge sharing and training to employees (Petrini and Pozzebon 2010; Wu- et al. 2012; Min and Galle 2001; Walker et al. 2008) have been found to be influencing firm performance. Firms response is also reported to be influenced by institutional members as it can change firms' viewpoints in terms of the cost involved and benefit achieved through environmental management (Nhemachena and Murimbika 2018; Zhu and Geng 2013; Sarkis et al. 2010; Lee 2008). Firm managers face various challenges while implementing sustainable practices most of which are related to the lack of financial and technical resources. As per the previous literature, excessive cost of raw materials and 
lack of financial resources is reported to be the most significant barrier faced by firms towards implementing sustainable practices (Lo et al. 2012; Na and Na 2015; Mittal and Sangwan 2014). Factors such as subsidized prices, inflation rate, and lack of enough infrastructure makes it even more difficult for firms to overcome the cost barrier (Gardetti and Torres 2017; Worrell et al. 2003; Jeswani et al. 2008; Chkanikova and Mont 2015). Alongside, factors such as the absence of mandatory regulations and policies towards the implementation of environment-friendly practices act as a barrier for firms. For developing countries, lack of requisite skills and expertise to adapt the technology to local conditions is considered as another important barrier hampering the growth of firms (TERI 1997; Jeswani et al. 2008).

Summarizing the literature, we find that industrial response towards environmental practices varies significantly across sectors and countries (Nhemachena and Murimbika 2018; Chico et al. 2013; Chiarini 2014; Van der Woerd et al. 2004). Factors influencing these responses revolve around various drivers and barriers in the form of regulations, economic conditions, market related factors and managerial, organizational aspects that help firm managers to implement sustainable business practices. Based on the discussion above, this research presents the following hypotheses;

H1. Regulatory pressure by the government, competitive influences and market demand positively influences the adoption of sustainable business practices by the Indian textile firm managers.

H2. Firms that face a lower level of economic, managerial, organizational, regulatory barriers are more likely to adopt sustainable practices.

\section{Methodology}

The section below discusses at length about questionnaire development, data collection methods and analysis tools used for this study.

\section{Instrument development}

We used a structured questionnaire to collect the data based on the primary survey, as this research design has successfully been used in similar previous studies (Theyel 2000; Wu- et al. 2012; Brunke et al. 2014). The items (questions) of the questionnaire were derived from previous literature and characteristics of textile industry.

The explanatory variables in this study include a set of drivers and barriers that influences the sustainable business practices of the textile companies. In order to assess the drivers, the questionnaire included items related to regulatory pressure, market competition and market demand. The items used in our study were adapted from previous studies (Wu- et al. 2012; Zhu et al. 2007). Similarly, for the barriers, we identified and modified items for managerial and organizational barriers (Trianni et al. 2013, J-C. Brunke et al. 2014; Ervin et al. 2013; Cagno et al. 2013; Rhodin et al. 2006; Harrington et al. 2008). For the dependent variable, we used a set of eighteen sustainable business practices items that are related to the product, process and supply chain by firms to implement sustainable practices (modified from Caniato et al. 2012). All items of the questionnaire were measured using 1-5 Likert type scale questions with choices - 1 (strongly disagree); 2 (disagree); 3 (Neutral); 4(agree); 5(strongly agree).

After the questionnaire was developed, it was reviewed by the subject experts and revised. The questionnaire was then pretested with on Indian textile industry experts, 
including three textile industry senior managers, one textile industry consultant with expertise in providing end to end solutions spanning the complete business cycles in the textile value chain and two academicians. Based on their feedback, the questionnaire was further revised before administering to the respondents (firm managers).

\section{Respondents}

The target respondents included of executives and senior-level managers with titles such as managing director, production heads, plant managers, sustainability head, technical head etc. These respondents were chosen because of their knowledge in textile supply chain operation and strategic management. Out of 202 firms, we could get data from 118 firms from which 113 were found to be complete thus resulting in a response rate of $55.94 \%$. The complete profile of firms and respondents has been displayed below (Table 1).

\section{Sampling and data collection}

Sample selection was done based on a list obtained from Confederation of Indian Textile Industry (CITI) in 2015 enlisting all textile firms on Bombay Stock Exchange (BSE). The list consisted of a total of 291 firms out of which we selected 202 firms which were lying in the north-western states of India, thereby covering $71.83 \%$ of total turnover of the textile industry. Only large-scale textile manufacturing firms dealing in cotton and yarn manufacturing (Spinning, weaving) and chemical producing firms (wet processing) were selected as they contribute towards creating more pollution and cotton textile segment accounts for around $75 \%$ of the total textile industry. Also, as the maximum number of environmental issues are at the stage of wet processing ${ }^{6}$ (which consists of dye houses) so the firms selected for this study also form part of the organized sector comprising of large composite mills ${ }^{7}$ and dye houses. For the purpose of this study, all primary data were collected from the identified firms located in all the five major states in North West region (Maharashtra, Gujrat, Rajasthan, Punjab, Delhi). of the country during July 2015-July 2017, .

All the identified companies were contacted and invited to participate in the study. After explaining the purpose of the study and seeking informed consent, questionnaires were distributed to all the respondents using three different methods - face to face, telephonic and online. Only those respondents who were willing to participate but were unavailable for face to face or telephonic survey interviews, were considered for online surveys. In addition to the regular questionnaire, a detailed online follow up was done with these respondents. The questionnaire consisted of 5-point Likert scale questions, in the first section, we collected the background information about the organization and on the position of the respondents in the organization, annual turnover, year of firm's establishment. The other sections of questionnaire were based upon drivers motivating firm mangers to take sustainable practices, sustainable business practices adopted by firm managers, barriers in implementation and benefits achieved). The follow up consisted of open-ended questions to gain insight into key areas where textile firms should focus to

\footnotetext{
${ }^{6}$ Wet Processing: Wet processing includes dyeing, printing and other cloth preparation prior to manufacture of clothing.

${ }^{7}$ Composite Mills: Composite mills are integrated large scale mills that integrate spinning, weaving and sometimes fabric finishing under one roof.
} 
Table 1 Profile of Firms \& Respondents

\begin{tabular}{|c|c|c|c|c|c|c|c|c|}
\hline No. of employees & $\mathrm{n}$ (firm) & $\%$ & Firm type & $\mathrm{n}$ (firm) & $\%$ & Informants' job title & $\mathrm{n}$ (person) & $\%$ \\
\hline Below 500 & 12 & 11 & Spinning mill & 31 & 27.4 & Production head & 31 & 27 \\
\hline $501-1000$ & 23 & 20 & Composite mill & 36 & 31.8 & Plant manager & 15 & 13 \\
\hline $1001-3000$ & 45 & 40 & Both & 46 & 40.7 & Processing/ Dyeing head & 13 & 12 \\
\hline $3001-5000$ & 13 & 12 & & & & Spinning/Weaving head & 16 & 14 \\
\hline \multirow[t]{3}{*}{$5001 \&$ above } & 19 & 17 & & & & Technical head/Quality control & 15 & 13 \\
\hline & & & & & & $\begin{array}{l}\text { Sustainability, Human } \\
\text { resource manager }\end{array}$ & 15 & 13 \\
\hline & & & & & & $\begin{array}{l}\text { Managing Director, Vice } \\
\text { President, Chairman }\end{array}$ & 8 & 7 \\
\hline
\end{tabular}

Total number of firms $n=113$

make their processes sustainable, sustainability initiatives undertaken by them and challenges faced in implementing environmentally sustainable practices.

\section{Description and construction of variables}

Dependent variable: Sustainable business practices.

Explanatory variable: Drivers and Barriers.

\section{Explanatory variables}

We have identified seven explanatory variables in the form of drivers and barriers to explain the changes in sustainable business practices.

\section{Regulatory pressure}

Several reviews of empirical studies suggest regulatory pressure to be positively influencing the firm's efforts towards environmental management (Darnall et al. 2008; Jeswani et al. 2008; Babiak and Trendafilov 2011; Lozano 2013; Ervin et al. 2013). For example, previous studies reported that firm managers were more receptive to regulatory factors and in participating in voluntary environmental programs (Delmas and Toffel 2004; Jeswani et al. 2008). In order to estimate the impact of regulatory pressure on sustainable business practices, we computed an index for regulatory pressure using the following components: national environmental regulations towards water, waste and energy efficiency was the reason to go sustainable; regional environmental regulations towards water, waste and energy efficiency was the reason to go sustainable; industry agreements was the reason for improving environmental performance. Principal component analysis (PCA) was used to derive the index.

\section{Market competition}

Competitive influences have been recognized as factors motivating firms to differentiate its product, increase firm's productivity and thereby influence them to adopt environment management practices. Empirical studies have found that market forces in form of competition and demand play an important role in firms' adoption of sustainable practices. Several empirical studies showed that stronger competitive pressure inclined companies to imitate competitor's business model, strengthen its competitive advantage and improve its image and performance (Chkanikova and Mont 2015; Jeswani et al. 2008; Søgaard 
Jørgensen et al. 2010; Wu- et al. 2012). India holds a significant position in global textile exports and textile manufacturers have to meet the environmental requirements of buyers to maintain its position in the market. This research assumes that market competition can influence firm managers towards improving their environmental performance. We estimated the impact of market competition on the firm's adoption of sustainable practices based on responses from Indian textile firm mangers. We computed an index for market competition using principal component analysis (PCA) using the following components: competitive pressure was the reason for our firm to adopt sustainability; the green initiative (following environmental standards) was part of our group sustainability activities; to maintain competitive position our firm took up sustainability practices.

\section{Demand from foreign buyers}

For the component on demand from foreign buyers we have used a dummy variable to represent the attitude of the firm towards a sustainable business practice based on foreign clients. If the domestic firm complies with sustainable practices based on foreign demand then the variable takes the value 1, 0 otherwise. A similar variable was significant in explaining green supply chain practices adopted by textile firms in Taiwan (Wu- et al. 2012). Previous research (Menguc et al. 2010) has shown market pressure to be positively influencing the firms managers commitment towards environmental protection, increasing investment in environmental management practices and encouraged environmental collaborations, thus we estimate a positive relationship between the impact of "demand from foreign buyers" on sustainable business practices.

\section{Managerial barriers}

Empirical studies suggest that manager's attitude and commitment play an important role in firms' adoption of environmental management practices and decision making (Petrini and Pozzebon 2010; Wu- et al. 2012; Min and Galle 2001; Walker et al. 2008). We attempted to estimate the impact of managerial barriers on the firm's adoption of sustainable business practices. We computed an index for managerial barriers using principal component analysis (PCA) using following components: lack of internal expertise on the environmental issue; lack of qualified human resources and capabilities to deal with environmental issues; lack of support from top management; communication gap from top management.

\section{Organizational barriers}

Adoption of sustainable business practices may also be influenced by firms' technological capabilities. Some studies suggest that firms with higher R\&D facilities could adopt more pollution prevention strategies towards greening their production chain (Harrington et al. 2008; Ervin et al. 2013). We computed an index for organizational barrier using principal component analysis. The components used are lack of internal technological facilities; lack of R\&D facilities; no specific benchmarking tool.

\section{Weak regulations}

For the component on weak regulations, we have used a dummy variable to capture the response of firms, If the domestic firm faces lack of support and information from 
the government to comply with sustainable practices then the variable takes the value as 1,0 otherwise.

\section{Economic barriers}

For the component on economic barriers, we have used a dummy variable if the firm faces economic barriers like the high cost of implementation and lack of financial resources, the variable takes the value 1,0 otherwise.

\section{Dependent variable}

\section{Sustainable business practices (SBP)}

We have measured the intensity of sustainable business practice with an index constructed using principal component analysis (PCA) of the responses to several questions regarding sustainable practices. The components used are presented in Table 3 below.

\section{Descriptive statistics analysis}

Table 2 and 3 below shows the descriptive statistics analysis which contains the mean, standard deviation, and number of samples for both explanatory and dependent variables. Except for managerial and organizational barriers, the mean of all other factors is greater than 3 of on a 5-point Likert scale. Demand from foreign buyers is highest amongst drivers and the economic barrier is the highest scale amongst barriers.

\section{Data analysis}

For this study, data were edited and scrutinized for correction and consistency. The principal component analysis was conducted in SPSS (version 17.0) to compute the indices for explanatory and dependent variables. PCA optimally weights chosen observed variables and combines them linearly to create new variables (Kennedy, 2003).

Multiple linear Regression analysis was used to estimate the relationships between the dependent (sustainable business practices) and explanatory variables (drivers and barriers) using STATA 12 software. We have run a model using the variables in their level form except for the two variables which we transformed into their log forms, namely, market competition and managerial barriers. Since these variables varied significantly in their scales when compared with the dependent variable, we had to transform the variables into a $\log$ form.

Multicollinearity and heteroscedasticity are often observed in estimations based on multivariate linear regression analysis. Multicollinearity was tested using the variance inflation factor (VIF). A low value of mean VIF (1.86) which is less than 10 indicates no problem of multicollinearity in the model. Breusch-Pagan / Cook Weisberg test was used to address the potential problem of heteroscedasticity. The Breusch -pagan heteroscedasticity indicated a higher probability value (0.2266) than chi-square (1.46) implying that the null hypothesis $\mathrm{HO}$ is not rejected and our results indicate an absence of heteroscedasticity.

\section{Results and discussion}

We estimated seven determinants of sustainable business practices for the Indian textile industry. These are the drivers and barriers which form the independent variables 
Table 2 Descriptive Statistics for Explanatory Variable (Drivers and Barriers)

\begin{tabular}{|c|c|c|c|c|c|}
\hline Variables & Mean & $\begin{array}{l}\text { Standard } \\
\text { deviation }\end{array}$ & $\mathrm{N}$ & Min. & Max. \\
\hline \multicolumn{6}{|l|}{ Regulatory Pressure } \\
\hline $\begin{array}{l}\text { National environmental regulations towards water, waste } \\
\text { and energy efficiency were the reasons to go sustainable }\end{array}$ & 4.107 & 1.025 & 112 & 1 & 5 \\
\hline $\begin{array}{l}\text { Regional environmental regulations towards water, waste } \\
\text { and energy efficiency were the reasons to go sustainable }\end{array}$ & 4.150 & 1.028 & 113 & 1 & 5 \\
\hline $\begin{array}{l}\text { Industry agreements were the reasons for improving } \\
\text { environmental performance. }\end{array}$ & 3.752 & 1.089 & 109 & 1 & 5 \\
\hline \multicolumn{6}{|l|}{ Market Competition } \\
\hline $\begin{array}{l}\text { Competitive pressure is the reason for our firm to adopt } \\
\text { sustainability }\end{array}$ & 3.767 & 1.030 & 112 & 1 & 5 \\
\hline $\begin{array}{l}\text { The green initiative was part of our group sustainability } \\
\text { activities }\end{array}$ & 4.107 & 0.798 & 112 & 2 & 5 \\
\hline $\begin{array}{l}\text { To maintain a competitive position our firm took up } \\
\text { sustainability practices. }\end{array}$ & 4.062 & 0.893 & 112 & 2 & 5 \\
\hline \multicolumn{6}{|l|}{ Market Demand } \\
\hline $\begin{array}{l}\text { Demand from foreign buyers was a driver for improving } \\
\text { environmental performance }\end{array}$ & 4.132 & 0.93 & 113 & 2 & 5 \\
\hline \multicolumn{6}{|l|}{ Managerial Barriers } \\
\hline Lack of internal expertise on an environmental issue & 2.709 & 1.167 & 110 & 1 & 5 \\
\hline $\begin{array}{l}\text { Lack of qualified human resources and capabilities to } \\
\text { deal with environmental issues }\end{array}$ & 2.684 & 1.167 & 111 & 1 & 5 \\
\hline Lack of support from top management acts as a barrier & 2.687 & 1.322 & 112 & 1 & 5 \\
\hline Communication gap from top management acts as a barrier & 2.455 & 1.214 & 112 & 1 & 5 \\
\hline \multicolumn{6}{|l|}{ Organizational Barrier } \\
\hline Lack of internal technological facilities & 2.774 & 1.117 & 111 & 1 & 5 \\
\hline Lack of R\&D facilities in this field & 2.836 & 1.169 & 110 & 1 & 5 \\
\hline No specific benchmarking tool & 3.288 & 0.877 & 111 & 1 & 5 \\
\hline \multicolumn{6}{|l|}{ Weak Regulations } \\
\hline $\begin{array}{l}\text { Lack of Support and information from government to } \\
\text { comply with sustainable practices }\end{array}$ & 3.099 & 1.19 & 111 & 1 & 5 \\
\hline \multicolumn{6}{|l|}{ Economic Barriers } \\
\hline $\begin{array}{l}\text { The high cost of raw materials required for implementation } \\
\text { acts as a barrier to go sustainable }\end{array}$ & 3.805 & 1.108 & 113 & 1 & 5 \\
\hline $\begin{array}{l}\text { Lack of financial resources required for implementation } \\
\text { acts as a barrier to go sustainable }\end{array}$ & 3.185 & 1.366 & 113 & 1 & 5 \\
\hline
\end{tabular}

used in our analysis to study their impact on sustainable business practices (SBP). Results for the multiple linear regression analysis are presented in Table 4 below.

The regression model showed $75 \%\left(R^{2}=0.75\right)$ variation in the adoption of sustainable business practices due to the determining drivers and barriers. The variable regulatory pressure indicates a significant and positive impact on the adoption of sustainable business practices at $1 \%$ significance level. This outcome suggests that environmental regulations by the government leads to an increase in the willingness of Indian textile firm managers to implement these practices and help them improve their environmental performance. During the survey, firm managers reported that launch of various initiatives by the Government of India such as introduction of Integrated Processing Development Scheme (IPDS) are the reasons behind firms initiative to follow environmental standards. The parks created under 
Table 3 Descriptive statistics for Dependent variable (Sustainable Business Practices)

\begin{tabular}{|c|c|c|c|c|c|}
\hline Variables & Mean & $\begin{array}{l}\text { Standard } \\
\text { deviation }\end{array}$ & $\mathrm{N}$ & Min. & Max. \\
\hline $\begin{array}{l}\text { We use recyclable and easily recoverable materials } \\
\text { during the design of clothes }\end{array}$ & 3.761 & 1.112 & 113 & 1 & 5 \\
\hline $\begin{array}{l}\text { We have a provision of lending our recyclable materials } \\
\text { (organic cotton waste, manufacturing scrap, old clothes) } \\
\text { to vendors for further use. }\end{array}$ & 3.633 & 1.565 & 112 & 1 & 5 \\
\hline $\begin{array}{l}\text { We enter new environmental markets to ensure sustainability } \\
\text { (e.g switched to organic cotton or sustainable fabrics where } \\
\text { water consumption is less) }\end{array}$ & 4.079 & 0.670 & 113 & 3 & 5 \\
\hline $\begin{array}{l}\text { We take initiatives to redesign products to be environmentally } \\
\text { sustainable such as to design clothes to avoid or reduce use of } \\
\text { hazardous products or manufacturing process. }\end{array}$ & 4.115 & 0.716 & 113 & 2 & 5 \\
\hline $\begin{array}{l}\text { We source locally with a focus on reducing transportation } \\
\text { time thereby limiting CO2 emissions linked to the movement } \\
\text { of goods thereby limiting of distances traveled for raw materials } \\
\text { and finished products }\end{array}$ & 4.309 & 0.641 & 113 & 2 & 5 \\
\hline $\begin{array}{l}\text { We use green parameter (GOTS, Oeko Tex, } 100 \text { etc./ certified) } \\
\text { as one of the criteria for our supplier selection }\end{array}$ & 3.982 & 0.731 & 113 & 2 & 5 \\
\hline $\begin{array}{l}\text { We execute an environmental audit for the supplier's internal } \\
\text { management }\end{array}$ & 4.345 & 0.741 & 113 & 2 & 5 \\
\hline $\begin{array}{l}\text { We take measures to reduce energy consumption in our } \\
\text { plants (e.g energy-efficient lighting, use of solar energy etc. }\end{array}$ & 4.451 & 0.681 & 113 & 2 & 5 \\
\hline $\begin{array}{l}\text { We use of water flow control devices to ensure that water } \\
\text { only flows to the process when needed. }\end{array}$ & 4.371 & 0.927 & 113 & 1 & 5 \\
\hline We follow emissions, effluents and waste management techniques. & 4.345 & 0.913 & 113 & 1 & 5 \\
\hline We use green materials in dyes, additives and other processes. & 3.937 & 0.903 & 112 & 1 & 5 \\
\hline We educate our suppliers about green initiatives. & 4.026 & 0.910 & 113 & 1 & 5 \\
\hline $\begin{array}{l}\text { Our chemical suppliers come up to us with green alternatives } \\
\text { (e.g use of peroxide bleach as less harmful for textiles) }\end{array}$ & 3.681 & 1.071 & 113 & 1 & 5 \\
\hline $\begin{array}{l}\text { We invest in R\&D to explore new sustainable methods to minimize } \\
\text { energy generation and waste disposal in production process. }\end{array}$ & 4.079 & 0.857 & 113 & 1 & 5 \\
\hline We cooperate with our suppliers for fulfilling environmental objectives. & 4.176 & 0.615 & 113 & 3 & 5 \\
\hline $\begin{array}{l}\text { We use leftover material for other activities postproduction } \\
\text { (disposed water from dyehouse used for gardening, reusing } \\
\text { cotton waste for making bags etc.) }\end{array}$ & 3.309 & 1.518 & 113 & 1 & 5 \\
\hline We have pollution control instruments / measures in place. & 4.159 & 0.701 & 113 & 2 & 5 \\
\hline We have a separate environment management team and professionals & 3.654 & 1.492 & 113 & 1 & 5 \\
\hline
\end{tabular}

Table 4 Multiple Linear regression analysis

\begin{tabular}{|c|c|c|c|}
\hline \multicolumn{4}{|c|}{$\begin{array}{l}\text { Multiple linear regression analysis - Sustainable Business Practice index on drivers and barriers } N=109 R^{2}= \\
0.750\end{array}$} \\
\hline S.no. & Drivers and barriers (Explanatory Variables) & $\beta$ Coefficients & Standard error \\
\hline 1 & Regulatory Pressure Index & $1.120^{* * *}$ & $(0.196)$ \\
\hline 2 & Market Competition Index (Ln) & $0.208^{* *}$ & $(0.0893)$ \\
\hline 3 & Demand from Foreign Buyers & $1.108^{* *}$ & $(0.476)$ \\
\hline 4 & Managerial Barriers Index (Ln) & 0.220 & $(0.166)$ \\
\hline 5 & Organizational Barriers Index & 0.239 & $(0.181)$ \\
\hline 6 & $\begin{array}{l}\text { Lack of Support \& information from Govt. } \\
\text { comply with sustainable practices }\end{array}$ & 0.407 & $(0.392)$ \\
\hline 7 & Economic Barrier & $-1.083^{* *}$ & $(0.487)$ \\
\hline
\end{tabular}


this scheme, deal with wastewater management and promote use of cleaner technology in textile processing thereby helping firm managers to strengthen textile production and make it more robust towards domestic and international markets. Often, productivity of textile industry is affected using obsolete machinery and outdated technology. Another initiative by the government in form of Amended Technology Upgradation Funds Scheme (ATUFS) provides subsidy to the textile firms towards technology upgradation. The effect of pressure from regulatory bodies shows that firms are willing to allocate resources to prevent environmental degradation with adequate support from government schemes, despite the cost constraints faced by them. They perceive pressure from regulations as opportunities to be more environmentally sustainable rather than taking it as threats. This result is coherent with previous findings (WU, G -C.et al. 2012; Darnall et al. 2008; Darnall and Edwards Jr 2006; Ervin et al. 2013), which revealed regulatory pressure as a significant motivator towards the adoption of environmental practices.

Furthermore, our results show that market competition impacts adoption of sustainable business practices at a 5\% significance level. In the recent years, major global textile and clothing brands have started their operations in India (H\&M, GAP, Levis, Addidas, Nike etc). These international brands are often more willing to follow environmental regulations and have the brand value to influence market towards adoption of environmentally sustainable practices. This indicates that firm managers often follow suit and develop an environmental strategy based upon global competitors. During the survey, textile firm managers reported initiatives such as establishing long term contractual relations with their vendors, contractors and agencies with established credentials on waste recycling towards improving environmental performance. They also reported initiative undertaken by them to ensure sustainability wherein waste generated during spinning of cotton is sold for further use for making low grade yarns and other home furnishing items. These initiatives help firms to diversify into new market segments, experience expansion of its global and domestic business, and as a result maintain its competitive position and experience an increase in market share. Firm managers also reported following textile standards during production process such as GOTS (Global Organic Textile Standards) and BCI (Better Cotton Initiative) during production. These standards define worldwide recognised requirements that ensure organic status of textiles including ecological and social criteria backed up by independent certification of the entire textile supply chain. These standards enable textile processors and manufacturers to export their organic fabrics with one certification accepted in all major markets, thereby resulting in expansion of business and overall profits for the firms. The variable demand from foreign buyers is found to be highly significant at $5 \%$ significance level with a positive sign which suggests that Indian textile firm managers develop an environmental strategy based on the encouragement from its buyers. Textiles are one of the oldest exports from India and the textile sector is one of the biggest beneficiaries of the Merchandise Exports from India Scheme ${ }^{8}$ (MEIS) (Ministry of Textiles, 2017), which offsets infrastructural inefficiencies and associated costs in export of goods. India holds a dominant position in the global textile exports, and textile manufacturers must meet the environmental requirements of domestic and international buyers. These results are also

\footnotetext{
${ }^{8}$ Merchandise Exports from India Scheme(MEIS): This scheme was introduced under Foreign trade policy (2015-2020) to offset infrastructural inefficiencies and associated costs involved in export of goods/products, which are produced / manufactured in India, especially those having high export intensity, employment potential and to enhance India's export competitiveness.
} 
coherent with previous findings for various industrial sectors (Zhu et al. 2007; Jeswani et al. 2008; Ervin et al. 2013; Prakash and Potoski 2007; Handfield et al. 2005). Together these results indicate that market forces in form of competition and demand positively influences firm managers decisions to adopt sustainable practices.

Results show that economic barriers negatively affect the adoption of sustainable business practices with 5\% significance level. Firms facing economic barriers in the form of high implementation cost and lack of financial resources are less likely to adopt these practices. The textile industry is capital intensive and financial recovery takes time. Indian textile firms often tend to adopt low cost technological options for production as they face monetary challenges in terms of limited resources and capital to invest in high cost technological upgradation. This result is consistent with previous findings that have reported cost constraints to be significant barriers faced by firm managers to implement environmental practices (Ervin et al. 2013; Johnstone and Labonne 2009; Jeswani et al. 2008). In contrast to the results discussed above, our study shows that managerial and organizational barriers reported amongst internal factors affecting the response of firms for developed countries are found to be statistically insignificant in the context of Indian textile firms. These barriers consist of factors such as lack of internal expertise on environmental issues, lack of qualified human resources and capabilities to deal with environmental issues, lack of support from top management, and communication gap from top management. The possible reason for these findings could be that the Indian textile firm mangers are in their initial phase of incorporating these practices. Also, the difference in economic and institutional pressures faced by firms in emerging economies as compared to developed nations could lead to this statistical trend. These findings are however consistent with similar studies on comparison of corporate response towards adopting environment management practices between developing and developed country (Jeswani et al. 2008; Prakash and Potoski 2007), where similar factors were reported to be insignificant from a developing country's perspective.

Overall, the result suggests that regulatory pressure, market competition, demand from foreign buyers and economic barriers significantly impacts the adoption of sustainable business practices for Indian textile firms. Thus, this model helps us better understand, while government policies and market forces play a significant role in motivating the Indian textile firms to embrace sustainability, economic barriers dampen this sustainable growth. Table 5 below presents a set of sustainable business practices adopted by firm managers towards improving its environmental performance .

\section{Conclusion and managerial implications}

This research contributes to the empirical findings in the context of textile firms on drivers and barriers affecting adoption of environmentally sustainable practices. The textile industry was chosen for its unavoidable set of sustainability issues on the environmental front. Our study concludes that Indian textile industry firm managers understand and accept that the issue of the natural environment and its protection is important for the performance and development of the textile industry. The empirical analysis of this research indicates that for Indian textile firms, a diverse set of factors consisting of regulatory, market and economic factors are more significant in pushing firms to adopt sustainable practices, whereas internal managerial and organizational barriers are not found to be significantly influencing the firm's practices. Thus, it is evident that the pressure on sustainability in textile firms comes from external factors 
Table 5 Sustainable Business Practices Adopted by Firms

\begin{tabular}{l} 
Variable \\
\hline Regulatory \\
Launch of \\
schemes by the \\
Government at \\
the national level \\
Provision of subsidy \\
by government \\
towards technology \\
upgradation. \\
Regional pollution \\
control regulations \\
by the government
\end{tabular}

Invest in R\&D to explore methods to minimize energy generation and waste disposal in production process.

Follow environmental standards

Follow emissions,

effluents and waste Redesigned pollution and waste control instruments.

(n)

$\begin{aligned} & \text { Measures taken by } \\ & \text { firms }\end{aligned}$
Follow environmental
standards.
Follow emissions,
effluents and waste
management techniques.
Redesigned pollution and
waste control instruments.

Sustainable business practices enabled management techniques.

Following the Global Organic Textile Standard (GOTS), Better Cotton Initiative (BCl)

Reduction in water

consumption.

Installation of biogas plants.

Replacement of old motors and old pumps by energy efficient motors and pumps which resulted in huge savings in terms of cost for the firms. Replacement of old fans by energy efficient plants in humidification plants. Installation of heat exchangers. Savings in steam through installation of heat recovery in dye house

Short term Total Quality Management (TQM) projects to reduce processing of dyes. Setup Reverse Osmosis (RO) plants to optimize water conservation, metering system across water distribution network.

Proper demarcation of wet and dry waste.

Invest in wastewater reuse and recyclable technology. Follow EPA rules for hazardous waste handling

Installation of plants for recycling polyester in which polyester fiber made through plastic

bottles and recycled materials. Mechanical vapor recompression technology which leads to savings of up to $80 \%$ energy at zero liquid discharge plants.

Separate environment management team and professionals
Market Competition and demand

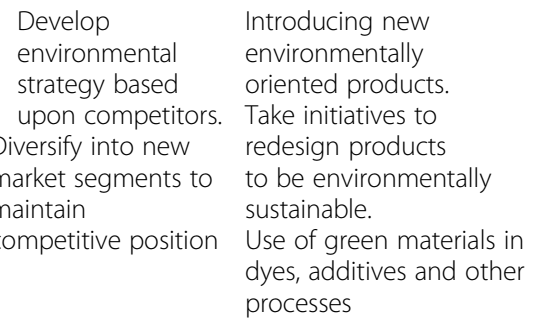

Total Quality Management (TQM) projects to improve recovery. Providing education to employees on bad practices. Targets given to production for less cuts and defects as it leads to wastage. Based on waste generated, waste management team to check if they can reuse that waste.

PIP (Productivity improvement program) to audit day to day manufacturing process.

Switched to organic cotton and sustainable fabrics where water consumption is less

To reduce water consumption and waste use of liquid indigo instead of powder for dyeing Registered under e-waste by government, collect all bio waste and use them for agriculture. Waterless dyeing and processing
Decrease in firm's energy emissions, water consumption and waste reduction. ${ }^{1}$ Positive impact on firm's environmental performance

Impact 
Table 5 Sustainable Business Practices Adopted by Firms (Continued)

\begin{tabular}{|c|c|c|c|}
\hline Variable & $\begin{array}{l}\text { Measures taken by } \\
\text { firms }\end{array}$ & $\begin{array}{l}\text { Sustainable business } \\
\text { practices enabled }\end{array}$ & Impact \\
\hline & & $\begin{array}{l}\text { that only uses scCO2 (super } \\
\text { critical carbon dioxide) to } \\
\text { replace water as carrier of } \\
\text { dyeing. } \\
\text { Condensate recovery system } \\
\text { installed in process house to } \\
\text { reduce fuel. }\end{array}$ & \\
\hline & $\begin{array}{l}\text { Use leftover material } \\
\text { for other activities } \\
\text { postproduction, } \\
\text { Useable waste used } \\
\text { inside company itself }\end{array}$ & $\begin{array}{l}\text { Waste generated during } \\
\text { spinning process is sold for } \\
\text { further use for making low grade } \\
\text { yarns and other home furnishing } \\
\text { items. } \\
\text { Use of organic cotton waste to } \\
\text { make recycled bags and t-shirts, } \\
\text { Recycling waste fabrics. } \\
\text { Sludge in form of dry waste } \\
\text { packed and transported to } \\
\text { secure landfill sites where solid } \\
\text { waste gets treated. } \\
\text { Effluent Treatment Plants (ETP) } \\
\text { and Sewage Treatment Plants } \\
\text { (STP) for treatment of } \\
\text { wastewater. } \\
\text { Disposed water from dye house } \\
\text { used for gardening purpose. }\end{array}$ & \\
\hline
\end{tabular}

rather than internal ones. However, internal factors if addressed would play a significant role in taking sustainability ahead in these firms. Based on this, we stress on giving more emphasis on the role of regulatory bodies to further strengthen the scope of sustainability for textile firms. The managers should also in-plug a sustainable business strategy from the very initial stages to help create that identity. Awareness of sustainable practices should be made part of the training.

In terms of regulations and cost constraints, the initial cost of compliance is the biggest challenge in implementing these practices. Apart from this, unpredictable policy change, low enforcement and awareness make it less acceptable among the manufacturers, hence there is a need to regulate cost. The textile associations should come up with specific policies concerning the issues in textile industry and help the government in chalking out these policies. Government must provide subsidies for companies willing to adopt environmental measures say for e.g. if some firm has established an Effluent treatment plant (ETP) then some reduction in subsidy should be given. Also, there should be no segregation between the interests of domestic and foreign buyers from the managerial end, once these are taken care of then the focus will come on including pollution prevention techniques. For example, for dyeing of clothes, two types of bleach chlorine vs peroxide bleach are being used. Chlorine is harmful so it is not used by textile manufacturers for export as it is restricted under environmental guidelines by foreign buyers whereas peroxide bleach is a costly option so used in less quantity for home country production due to lack of stringent regulation. We recommend that strengthening of national and regional regulations will assist companies in adopting the proactive environmental strategy thereby assisting in making optimal choices and dedicating themselves to more comprehensive environmental practices. 


\section{Implications for future research}

Through our research, we contribute to the existing literature on motivations and barriers to pursuing environmental sustainability by the firm. We specifically address these issues concerning the textile industry in India. Given the significance of the industry from the perspective of global demand and sustainable consumption and production (SDG 12), our study brings interesting findings related to firms' strategies and intent behind these strategies. The study gives answers to the questions: Why textile firms in India pursue environmental strategies? Which barriers do they face? The study is limited in its understanding of a limited number of barriers and drivers constrained by a limited number of samples. Secondly, we are estimating factors affecting sustainable business practices of the firms. For instance, we tested the hypothesis that a foreign buyer's demand affects the firm's decision regarding sustainable business practices (SBPs). But SBPs of the firms may have an impact on the decision of foreign customers. In such a situation, there is a simultaneous relationship between the explanatory variable and the dependent variable. This makes the explanatory variable endogenous and one of the assumptions of the classical linear regression model gets refuted. Future research can also consider the role of environmental certifications on how it affects the adoption of sustainable practices. Organizational and managerial barriers are found to be insignificant for this study. However, these factors can be compared across textile firms in other developing countries where they may be significant. Future studies may investigate how other stakeholders of the textile supply chain perceive the barriers and what collaborative efforts could be made to remove these barriers. Hence, a more comprehensive study from an internal and external stakeholder perspective could be very useful. Given the financial stress that many textile firms are facing, it would be worthwhile to explore the relationship between indicators of financial sustainability and environmental sustainability. Further studies could study in detail the understanding of these firms about the Sustainable Consumption and Production (SCP) indicators and efforts towards their implementation. A study of both environmental and social indicators could also be useful from the consumer perspective.

A few more research problems could be taken up: How is managerial awareness and attitude about the environment leading to influence firms' strategies? What is the relationship between consumers' demand and firms' adoption of sustainable business practices? How are firms' environmental performance and financial performance related and how they influence each other?

Acknowledgements

The authors are thankful to all the respondents at the studied firms for giving their time and attention to answer the questions.

Authors' contributions

AS carried out the empirical study, the literature review and drafted the manuscript. SN planned the study along with the AS and provided overall guidance throughout the research including setting the research plan, designing of questionnaire; also checked the drafts of the paper and participated in the statistical analysis and communicated with the editor of the journal. Both the authors read and approve the final manuscript.

Authors' information

The author presently works as Professor \& Dean, School of Management Studies, Nalanda University but the work was carried out and submitted while she worked as Associate Professor \& Head, Deptt. of Business \& Sustainability, TERI

School of Advanced Studies.

Funding

Not Applicable. 


\section{Availability of data and materials}

The study is based on primary data. Data have been collected based on structured questionnaire designed by authors. The datasets used and/or analyzed during the current study are available from the corresponding author on reasonable request.

\section{Competing interests}

The authors declare that they have no competing interests.

Received: 17 July 2019 Accepted: 3 January 2020

Published online: 12 March 2020

\section{References}

Abernathy FH, Volpe A, Weil D (2006) The future of the apparel and textile industries: prospects and choices for public and private actors. Environ Plan A 38(12):2207-2232

Achabou MA, Dekhili S (2015) Constraints and drivers of growth in the ethical fashion sector: the case of France. In: Sustainable fashion supply chain management. Springer, Cham, pp 167-181

Akenji L, Bengtsson M (2014) Making sustainable consumption and production the core of sustainable development goals. Sustainability 6(2):513-529

Alkaya E, Demirer GN (2014) Sustainable textile production: a case study from a woven fabric manufacturing mill in Turkey. J Clean Prod 65:595-603

Allwood JM, Laursen SE, de Rodriguez CM, Bocken NM (2015) Well dressed? The present and future sustainability of clothing and textiles in the United Kingdom. J Home Econ Inst Aust 22(1):42

Allwood JM, Laursen SE, Russell SN, de Rodríguez CM, Bocken NMP (2008) An approach to scenario analysis of the sustainability of an industrial sector applied to clothing and textiles in the UK. J Clean Prod 16(12):1234-1246

Almeida L (2015) Ecolabels and organic certification for textile products. In: Roadmap to sustainable textiles and clothing. Springer, Singapore, pp 175-196

Arora A, Jaju A, Kefalas AG, Perenich T (2004) An exploratory analysis of global managerial mindsets: a case of US textile and apparel industry. J Int Manag 10(3):393-411

ASSOCHAM (2010) Eco pulse: India textile scenario, http://www.FIBER2fashion.com/ industry-article/21/2042/indias-textileindustry-still-spinning-a-gloomy-tale1.Asp, Accessed 14 Nov 2013

Azapagic A, Perdan S (2000) Indicators of sustainable development for industry: a general framework. Process Saf Environ Prot 78(4):243-261

Babiak K, Trendafilov S (2011) CSR and environmental responsibility: motives and pressures to adopt green management practices. Corp Soc Responsib Environ Manag 18(1):11-24

Baskaran V, Nachiappan S, Rahman S (2012) Indian textile suppliers' sustainability evaluation using the grey approach. Int J Prod Econ 135(2):647-658

Beske P, Land A, Seuring S (2014) Sustainable supply chain management practices and dynamic capabilities in the food industry: a critical analysis of the literature. Int J Prod Econ 152:131-143

Blackburn R (2009) Sustainable textiles: life cycle and environmental impact. Elsevier

Bonini SM, Mendonca LT, Oppenheim JM (2006) When social issues become strategic. McKinsey Q 2:20

Brunke JC, Johansson M, Thollander P (2014) Empirical investigation of barriers and drivers to the adoption of energy conservation measures, energy management practices and energy services in the Swedish iron and steel industry. J Clean Prod 84:509-525

Cagno E, Trianni A (2014) Evaluating the barriers to specific industrial energy efficiency measures: an exploratory study in small and medium-sized enterprises. Journal of Cleaner Production 82:70-83.

Caniato F, Caridi M, Crippa L, Moretto A (2012) Environmental sustainability in fashion supply chains: an exploratory casebased research. Int J Prod Econ 135(2):659-670

Chen HL, Burns LD (2006) Environmental analysis of textile products. Cloth Text Res J 24(3):248-261

Chiarini A (2014) Strategies for developing an environmentally sustainable supply chain: differences between manufacturing and service sectors. Bus Strateg Environ 23(7):493-504

Chico D, Aldaya MM, Garrido A (2013) A water footprint assessment of a pair of jeans: the influence of agricultural policies on the sustainability of consumer products. J Clean Prod 57:238-248

Chkanikova O, Mont O (2015) Corporate supply chain responsibility: drivers and barriers for sustainable food retailing. Corp Soc Responsib Environ Manag 22(2):65-82

Christmann P, Taylor G (2001) Globalization and the environment: determinants of firm self-regulation in China. J Int Bus Stud 32(3):439-458

Chugan PK (2011) Diversification into technical textiles: a forward momentum for Indian textiles industry. J Bus Manag Stud 6:18-31

CITI (2018) Disruptions and innovation for sustainable growth. Retrieved from http://www.citiindia.com/wp-content/ uploads/2018/12/Textile-Times_oct-nov-2018.pdf

Clemens B (2001) Changing environmental strategies over time: an empirical study of the steel industry in the United States. J Environ Manag 62(2):221-231

Da Silva RV, Teixeira N (2008) Environmental business strategy: the Portuguese case. Bus Strateg Environ 17(3):208-218

Darnall N, Edwards D Jr (2006) Predicting the cost of environmental management system adoption: the role of capabilities, resources and ownership structure. Strateg Manag J 27(4):301-320

Darnall N, Jolley GJ, Handfield R (2008) Environmental management systems and green supply chain management: complements for sustain ability? Bus Strateg Environ 17(1):30-45

Dasgupta J, Sikder J, Chakraborty S, Curcio S, Drioli E (2015) Remediation of textile effluents by membrane-based treatment techniques: a state-of-the-art review. J Environ Manag 147:55-72

Daub CH, Ergenzinger R (2005) Enabling sustainable management through a new multi-disciplinary concept of customer satisfaction. Eur J Mark 39(9/10):998-1012 
De Abreu MCS (2015) Perspectives, drivers, and a roadmap for corporate social responsibility in the textile and clothing industry. In: Roadmap to sustainable textiles and clothing. Springer, Singapore, pp 1-21

De Brito MP, Carbone V, Blanquart CM (2008) Towards a sustainable fashion retail supply chain in Europe: organisation and performance. Int J Prod Econ 114(2):534-553

Defra (UK Department for Environment, Food and Rural Affairs) (2008) Sustainable clothing roadmap briefing note December 2007: sustainability impacts of clothing and current interventions. Defra, London

Delmas M, Toffel MW (2004) Stakeholders and environmental management practices: an institutional framework. Bus Strateg Environ 13(4):209-222

DeSimone LD, Popoff F (1998) Eco-efficiency. The business link to sustainable development. 2nd printing

Desore A, Narula SA (2018) An overview on corporate response towards sustainability issues in textile industry. Environ Dev Sustain 20(4):1439-1459

Diabat A, Kannan D, Mathiyazhagan K (2014) Analysis of enablers for implementation of sustainable supply chain management-a textile case. J Clean Prod 83:391-403

Dos Santos AB, Cervantes FJ, van Lier JB (2007) Review paper on current technologies for decolourisation of textile wastewaters: perspectives for anaerobic biotechnology. Bioresour Technol 98(12):2369-2385

Eccles RG, Perkins KM, Serafeim G (2012) How to become a sustainable company. MIT Sloan Manag Rev 53(4):43-50

Elliot S (2013) A transdisciplinary exploratory model of corporate responses to the challenges of environmental sustainability. Bus Strateg Environ 22(4):269-282

Elkington, J. (1998). Partnerships from cannibals with forks: The triple bottom line of 21 st-century business. Environmental quality management, 8(1), 37-51.

Ervin D, Wu J, Khanna M, Jones C, Wirkkala T (2013) Motivations and barriers to corporate environmental management. Bus Strateg Environ 22(6):390-409

Fletcher K (2008) Sustainable fashion and textiles: design journeys, Earthscan. Sterling, London

Fletcher K (2009) Systems Change for Sustainability in Textiles. In R.S. Blackburn (ed.), Sustainable Textiles: Life Cycle and Environmental Impact. Cambridge, UK: Woodhead Publishing Limited.

Fletcher K, Grose L (2012) Fashion and sustainability: design for change. Laurence King

G. Hansen E, Schaltegger S (2013) 100 per cent organic? A sustainable entrepreneurship perspective on the diffusion of organic clothing. Corp Gov 13(5):583-598

Gardetti MA, Torres AL (Eds.) (2012) Textiles, fashion and sustainability: a special theme issue of the journal of corporate citizenship (issue 45) (no. 45). Greenleaf Publishing

Gardetti MA, Torres AL (2017) Sustainability in fashion and textiles: values, design, production and consumption. Routledge

Goworek H, Fisher T, Cooper T, Woodward S, Hiller A (2012) The sustainable clothing market: an evaluation of potential strategies for UK retailers. Int J Retail Distrib Manag 40(12):935-955

Gupta M, Hodges N (2012) Corporate social responsibility in the apparel industry: an exploration of Indian consumers' perceptions and expectations. J Fashion Mark Manag 16(2):216-233

Handfield R, Sroufe R, Walton S (2005) Integrating environmental management and supply chain strategies. Bus Strateg Environ 14(1):1-19

Harrington DR, Khanna M, Deltas G (2008) Striving to be green: the adoption of total quality environmental management. Appl Econ 40:2995-3007

Hasanbeigi A, Price L (2012) A review of energy use and energy efficiency technologies for the textile industry. Renew Sust Energ Rev 16:3648-3665

Herva M, Franco A, Ferreiro S, Álvarez A, Roca E (2008) An approach for the application of the ecological footprint as environmental indicator in the textile sector. J Hazard Mater 156(1-3):478-487

Hethorn J, Ulasewicz C (eds) (2008) Sustainable fashion, why now? A conversation about issues, practices, and possibilities. Fairchild Books, New York

Hiremath RB, Kattumuri R, Kumar B, Khatri VN, Patil SS (2012) An integrated networking approach for a sustainable textile sector in Solapur, India. Urbani izziv 23(2):140-151

Hong GB, Su TL, Lee JD, Hsu TC, Chen HW (2010) Energy conservation potential in Taiwanese textile industry. Energy Policy 38(11):7048-7053

Jeswani HK, Wehrmeyer W, Mulugetta Y (2008) How warm is the corporate response to climate change? Evidence from Pakistan and the UK. Bus Strategy Environ 17(1):46-60

Joergens C (2006) Ethical fashion: myth or future trend? J Fashion Mark Manag 110(3):360-371

Johnstone N, Labonne J (2009) Why do manufacturing facilities introduce environmental management systems? Improving and/or signalling performance. Ecol Econ 68:719-730

Joyce A, Paquin RL (2016) The triple layered business model canvas: a tool to design more sustainable business models. J Clean Prod 135:1474-1486

Kalliala E, Talvenmaa P (2000) Environmental profile of textile wet processing in Finland. J Clean Prod 8(2):143-154

Kane CD (2001) Environmental and health hazards in spinning industry and their control

Karthik T, Gopalakrishnan D (2014) Environmental analysis of textile value chain: An overview. In: Muthu SS (ed) Roadmap to sustainable textiles and clothing, textile science and clothing technology,edition: 2014, chapter: Environmental analysis of textile value chain: an overview. Springer, Singapore, pp 153-188

Kennedy P (2003) A guide to econometrics. MIT press.

Lee SY (2008) Drivers for the participation of small and medium-sized suppliers in green supply chain initiatives. Supply Chain Manag 13(3):185-198

Lo CK, Yeung AC, Cheng TCE (2012) The impact of environmental management systems on financial performance in fashion and textiles industries. Int J Prod Econ 135(2):561-567

Lozano R (2013) Are companies planning their organisational changes for corporate sustainability? An analysis of three case studies on resistance to change and their strategies to overcome it. Corp Soc Responsib Environ Manag 20(5):275-295

Menguc B, Auh S, Ozanne L (2010) The interactive effect of internal and external factors on a proactive environmental strategy and its influence on a firm's performance. J Bus Ethics 94:279-298

Min H, Galle WP (2001) Green purchasing practices of US firms. In J Oper Prod Manag 21(9):1222-1238 
Ministry of textiles, Annual report (2017-2018), retrieved from http://www.texmin.nic.in/sites/default/files/AnnualReport2017-1 8\%28English\%29.pdf

Mittal VK, Sangwan KS (2014) Prioritizing barriers to green manufacturing: environmental, social and economic perspectives. Procedia CIRP 17:559-564

Na Y, Na DK (2015) Investigating the sustainability of the Korean textile and fashion industry. Int J Cloth Sci Technol 27(1):23-33

Narayanaswamy V, Scott JA (2001) Lessons from cleaner production experiences in Indian hosiery clusters. J Clean Prod 9(4): $325-340$

Nhemachena C, Murimbika M (2018) Motivations of sustainable entrepreneurship and their impact of enterprise performance in Gauteng Province. Business Strategy Development, South Africa

Nieminen E, Linke M, Tobler M, Vander Beke B (2007) EU COST action 628: life cycle assessment (LCA) of textile products, eco-efficiency and definition of best available technology (BAT) of textile processing. J Clean Prod 15(13-14):1259-1270

Niinimäki K, Hassi L (2011) Emerging design strategies in sustainable production and consumption of textiles and clothing. J Clean Prod 19(16):1876-1883

O'Cass A, Weerawardena J (2010) The effects of perceived industry competitive intensity and marketing-related capabilities: drivers of superior brand performance. Ind Mark Manag 39(4):571-581

Ozturk E, Karaboyacı M, Yetis U, Yigit NO, Kitis M (2015) Evaluation of integrated pollution prevention control in a textile fiber production and dyeing mill. J Clean Prod 88:116-124

Parvathi C, Maruthavanan T, Prakash C (2009) Environmental impacts of textile industries. Indian Textile J 22

Pedersen ERG, Andersen KR (2014) The SocioLog. dx experience: a global expert study on sustainable fashion. Copenhagen: DE.

Petrini M, Pozzebon M (2010) Integrating sustainability into business practices: learning from Brazilian firms. BAR-Brazilian Adm Rev 7(4):362-378

Prakash A, Potoski M (2007) Investing up: FDI and the cross-country diffusion of ISO 14001 management systems. Int Stud Q 51(3):723-744

Pullman ME, Maloni MJ, Carter CR (2009) Food for thought: social versus environmental sustainability practices and performance outcomes. J Supply Chain Manag 45(4):38-54

Reddy BS, Ray BK (2011) Understanding industrial energy use: physical energy intensity changes in Indian manufacturing sector. Energy Policy 39(11):7234-7243

Resta B, Dotti S, Pinto R, Gaiardelli P (2013) A decision-making process for sustainability in the textile sector. In: IFIP international conference on advances in production management systems. Springer, Berlin, Heidelberg, pp 418-425

Rieple A, Singh R (2010) A value chain analysis of the organic cotton industry: the case of UK retailers and Indian suppliers. Ecol Econ 69(11):2292-2302

Rhodin P, Thollander P, Solding P (2006) Barriers to and driving forces for energy efficiency in the Swedish foundry industry Energy Policy 35:1836-44

Sarkis J, Gonzalez-Torre P, Adenso-Diaz B (2010) Stakeholder pressure and the adoption of environmental practices: the mediating effect of training. J Oper Manag 28(2):163-176

Schrettle S, Hinz A, Scherrer -Rathje M, Friedli T (2014) Turning sustainability into action: Explaining firms' sustainability efforts and their impact on firm performance. International Journal of Production Economics 147:73-84.

Sezen B, Çankaya SY (2013) Effects of green manufacturing and eco-innovation on sustainability performance. Procedia Soc Behav Sci 99:154-163

Shen B (2014) Sustainable fashion supply chain: lessons from HM. Sustainability 6(9):6236-6249

Shen B, Li Q, Dong C, Perry P (2017) Sustainability issues in textile and apparel supply chains, p 1592

Shrivastava P (1995) The role of corporations in achieving ecological sustainability. Acad Manag Rev 20(4):936-960

Simi TB (2012) Indian textile clothing sector environmental standards and consumer knowledge in the EU. Briefing paper. CUTS International CITEE (2)

Singh SP, Jena PC, Singh NK (2013) Cotton production and environmental sustainability in India. CUTS International

Søgaard Jørgensen M, Jørgensen U, Hendriksen K, Hirsbak S, Holmlund Thomsen H, Thorsen N (2010) Environmental management in Danish transnational textile product chains. Manag Res Rev 33(4):357-379

Tata Energy Research Institute (TERI) (1997) Capacity building for technology transfer in the context of climate change. TERI New Delhi

Theyel G (2000) Management practices for environmental innovation and performance. Int J Oper Prod Manag 20(2):249-266

Thiry MC (2011) Staying alive: making textiles sustainable. AATCC Rev 11:26-32

Tortella BD, Tirado D (2011) Hotel water consumption at a seasonal mass tourist destination. The case of the island of Mallorca. J Environ Manag 92(10):2568-2579

Trianni A, Cagno E, Thollander P, Backlund S (2013) Barriers to industrial energy efficiency in foundries: a European comparison. Journal of Cleaner Production 40:161-176.

Vajnhandl S, Valh JV (2014) The status of water reuse in European textile sector. J Environ Manag 141:29-35

Van der Woerd KF, de Wit CM, Kolk A, Levy DL, Vellinga P, Behlyarova E (2004) Diverging business strategies towards climate change: a USA-Europe comparison for four sectors of industry

Verma S (2002) Export competitiveness of Indian textile and garment industry. Indian Council for Research on International Economic Relations, Working Paper, (94)

Walker H, Di Sisto L, McBain D (2008) Drivers and barriers to environmental supply chain management practices: lessons from the public and private sectors. J Purch Supply Manag 14(1):69-85

Welford R (2005) Corporate social responsibility in Europe and Asia. J Corp Citizsh 17:33-52

Wenzel H, Knudsen HH (2005) Water savings and reuse in the textile industry. In: Modern tools and methods of water treatment for improving living standards. Springer, Dordrecht, pp 169-189

Worrell E, Laitner JA, Ruth M, Finman H (2003) Productivity benefits of industrial energy efficiency measures. Energy 28(11): 1081-1098

Wu- GC, Ding JH, Chen PS (2012) The effects of GSCM drivers and institutional pressures on GSCM practices in Taiwan's textile and apparel industry. Int J Prod Econ 135(2):618-636 
Zabaniotou A, Andreou K (2010) Development of alternative energy sources for GHG emissions reduction in the textile industry by energy recovery from cotton ginning waste. J Clean Prod 18(8):784-790

Zhu Q, Geng Y (2013) Drivers and barriers of extended supply chain practices for energy saving and emission reduction among Chinese manufacturers. J Clean Prod 40:6-12

Zhu Q, Sarkis J (2006) An inter-sectoral comparison of green supply chain management in China: drivers and practices. J Clean Prod 14(5):472-486

Zhu Q, Sarkis J, Lai KH (2007) Initiatives and outcomes of green supply chain management implementation by Chinese manufacturers. J Environ Manag 85(1):179-189

Zhu QH, Sarkis J, Geng Y (2005) Green supply chain management in China: pressures, practices and performance. Int J Oper Prod Manage 25:449-468

\section{Publisher's Note}

Springer Nature remains neutral with regard to jurisdictional claims in published maps and institutional affiliations.

Submit your manuscript to a SpringerOpen ${ }^{\odot}$ journal and benefit from:

- Convenient online submission

- Rigorous peer review

- Open access: articles freely available online

- High visibility within the field

- Retaining the copyright to your article

Submit your next manuscript at $\boldsymbol{\nabla}$ springeropen.com 